Acta Theriologica 39 (1): 59-66, 1994.

PL ISSN 0001-7051

\title{
Reproduction in otters in Belarus and north-western Russia
}

\author{
Vadim E. SIDOROVICH and Igor L. TUMANOV
}

\begin{abstract}
Sidorovich V. E. and Tumanov I. L. 1994. Reproduction in otters in Belarus and north-western Russia. Acta theriol. 39: 59-66.

Between 1967 and 1991, otters Lutra lutra (Linnaeus, 1758) were collected from Belarus and NW Russia (St. Petersburg, Pskov, and Novgorod regions). Reproductive status was assessed by histological study of the reproductive organs of 99 otters. Reproductive maturity was recorded in otters $\geq 2$ years old. No definite breeding period could be determined. The uteri of 10 females contained from 2 to 4 non-resorbing embryos, 2.6 on average. The sizes of 81 litters of blind cubs were counted; an average of 2.6 cubs per litter was recorded.

Institute of Zoology, Belarussian Academy of Sciences, 27 F. Skoriny Str., Minsk 220072, Belarus (VES); Western Zone Laboratory, B. U. Zhitkov Research Institute of Game Management and Fur Farming, 1 Linia 38, Vasilevsky Ostrov, Sankt-Petersburg - 199053, Russia (ILT)

Key words: Lutra lutra, fecundity, litter size, sexual cycle, Belarus, Russia
\end{abstract}

\section{Introduction}

Reproduction in the wild is one of the least understood aspects of otter Lutra lutra (Linnaeus, 1758) biology (Erlinge 1967, Vshivtsev 1972, Heptner and Naumov 1974, Danilov and Tumanov 1976, Stubbe 1977, Wayre 1979, Jenkins 1980, Jenkins and Harper 1982, Trowbridge 1983, Mason and Macdonald 1986, Kruuk et al. 1987, Sidorovich 1991). Although the reproduction of captive otters has been studied in some detail, many aspects of reproduction in the wild are still poorly known, including the timing of the cycles of female oestrus and male spermatogenesis, the timing of mating and its relation to age, and duration of pregnancy and anoestrus. Female maturity, the role of the female in copulation, fecundity, and the dependence of these characters on population density also invite further investigation.

\section{Methods and material}

Otters were collected between 1967 and 1991 from the regions of Belarus, and the adjacent part of Russia: St. Petersburg (Leningrad), Pskov and Novgorod regions. Reproductive condition was examined by histological study of the reproductive organs of 81 otters aged $\geq 1$ year (37 males, 44 females) and of 18 otters aged $<1$ year.

Tissues were fixed in $10 \%$ neutral buffered formalin, dehydrated in serial dilutions of alcohol, and embedded in parafin wax. Sections were cut to $7-10 \mu \mathrm{m}$ and stained in iron haematoxylin following 
Cler (1941), Shell (1955) and Danilov and Tumanov (1976). The ovaries, uterus and vagina of all females were examined, but only testes with epididymes from the males.

Embryos were found in the uteri of 10 females, and holts containing litters of up to four blind cubs (aged $<1$ month) were located with the help of other workers and hunters. All these data were used to characterise otter fecundity and reproductive cycles.

The role of the female in reproduction was investigated from records of the proportions of pregnant females, and also from recording the proportion of adult females with litters located during riverbank searches (see Sidorovich 1991). The ages of otters taken by hunters $(n=99)$ were determined from the degree of fusion of the cranial sutures (Stubbe 1969) and from studies of tooth band structure (Klevezal and Kleinenberg 1967, Stephenson 1977, Heggberget 1984). All data included capture dates, the name of the waterbody and its administrative region, and ecological characteristics.

\section{Results}

\section{Males}

The testes of males aged $0-1$ year $(n=18)$ and $1-2$ years $(n=10)$ were underdeveloped. The seminiferous tubules of first year males $(n=11)$ had a single row of epithelium consisting of Sertoli cells and primary spermatogonia. Second year males $(n=6)$ taken in April and June, and between October and December, showed increased levels of mitosis in the germinal epithelium of the tubules. In April, in addition to Sertoli cells and spermatogonia, the germinal epithelium also featured layers of primary and secondary spermatocytes. In June (and the other months), some individuals showed active spermatogenesis, but not beyond the stage of spermatocytes or spermatids. The weight of both testes (with epididymes) in juveniles $0-1$ and $1-2$ years old $(n=17)$ did not exceed $1.8 \mathrm{~g}$. Males aged $\geq 2$ years showed considerably increased testes weights, particularly in autumn, winter and spring (Table 1).

Table 1. Annual changes in the genital weights (in grams) of otters aged $\geq 2$ years from Belarus and NW Russia.

\begin{tabular}{lll}
\hline Month & \multicolumn{1}{c}{$\begin{array}{c}\text { Males }(n=22) \\
\text { (testes with epididymes) }\end{array}$} & $\begin{array}{c}\text { Females }(n=7) \\
\text { (ovaries) }\end{array}$ \\
\hline January & 4.4 & 5.8 \\
February & 9.2 & - \\
March & $2.1,9.7$ & $5.0,8.0$ \\
April & $11.3,7.0,6.3,3.8,12.0$ & - \\
May & $2.1,9.7$ & - \\
June & 4.5 & - \\
July & 2.3 & - \\
August & - & - \\
September & $8.8,3.7$ & - \\
October & 6.0 & - \\
November & $7.2,12.6,8.8,11.0,11.5,6.5$ & 10.5 \\
December & - & $4.0,3.7,23.0$ \\
\hline
\end{tabular}


Analysis shows that all males captured between February and May $(n=12)$ were sexually functional. Spermatogenesis was intense in the seminiferous tubules, and the epididymes were full of sperm. Only a single male (aged 6+) taken at the beginning of May, showed the onset of spermatogenesis. The germinal epithelium of this individual appeared to be two-rowed and consisted of Sertoli cells, spermatogonia, primary and secondary spermatocites, and small number of spermatids.

Due to the shortage of specimens collected during summer $(n=3)$ it was not possible to make definitive conclusions on the availability of males for mating between July and August. Two males (taken in June and July) displayed termination of passive spermatogenesis, but the development of mature sex cells was not yet complete. The third male (taken in July) was close to the sexual resting phase; the germinal epithelium of the seminiferous tubules showing regression, with cell elements in their terminal phase.

During period from September to December, all the males examined $(n=22)$ had testes bearing sex cells, ranging from spermatogonia to spermatozoa, providing evidence of sexual maturity. However, reproductive readiness in males appears to be asynchronous, particularly in October and early November. During this period, some males showed high levels of functional activity, others displayed the initial phases of active spermatogenesis, whilst a certain proportion showed a definite decrease in functional activity. In the last case, the seminiferous tubules were noticeably separated by interstitial tissues, and testes sections showed the presence of only a small number of mature sex cells in some of the tubules.

\section{Females}

All the sexually active females were older than 2 years, the uteri of first-year females being thin and infantile. In autumn, the uteri (including the uterine horns and the ovaries) weighed $440-480 \mathrm{~g}$, the length of the horns was $35-45 \mathrm{~mm}$, and their outer diameter was only $3.5-4.2 \mathrm{~mm}$. The ovaries had only primordial and small, developing follicles $150-200 \mu \mathrm{m}$ in size, and the vaginal epithelium was only two or three layers deep. Approximately the same state was characteristic of juvenile females aged 1-2 years. Here there were two or three rows of vaginal epithelium, the uterus walls were thin, and the glandular layer was weakly developed. The ovaries contained small, medium-sized or regressing follicles $(<400-500 \mu \mathrm{m})$, and the weight of the uteri (including both horns and ovaries) was $750-3250 \mathrm{~g}$. The horn lengths and outer diameter were $37-58 \mathrm{~mm}$ and $3.5-5.2$ $\mathrm{mm}$, respectively.

The reproductive organs of adult females were noticeably larger. In the breeding period the horns of the uteri were $55-78 \mathrm{~mm}$ and their diameter was $6.2-8.5 \mathrm{~mm}$. Four-year old female taken in January had active reproductive organ, and was characterised as pro-oestral. The uterine wall was enlarged and bloodshot, the 
lumen star-shaped, and the ovary contained many large, mature follicles $(1200-1600 \mu \mathrm{m})$. The only adult female taken at the beginning of February was pregnant, each uterine horn carrying two poorly developed embryos.

Four females taken in March and April were also pregnant. In two females taken at the end of March, corpora lutea were clearly visible, and the uterine horns showed thick foetal bulges. Two females taken in April had either two or three fully developed embryos. All other adult females taken in March or April $(n=9)$ were either pro-oestral, or oestral, some having a bloodshot uterus with well developed glands. Here the uterine epithelium was of the raised cuboidal type, and the ovaries contained many large follicles $(800-900 \mu \mathrm{m})$ (i.e. pro-oestral: Danilov and Tumanov 1976). Other adult females caught during the same period were ready for mating. Their vaginal epithelium consisted of 10-12 rows of cells. The cells of the superficial layers had already become enucleate, and the cornified cells were in the process of separation. The uterine cavity was star-shaped, the muscular walls noticeably thickened and bloodshot, and the secretions of the uterine glands were visible within the lumen. The ovaries contained either ovulated follicles in the initial stage of corpora lutea formation, or Graafian follicles on the point of rupture, their diameter reaching $1200-1500 \mu \mathrm{m}$. The ovaries also contained both regressing $(<450 \mu \mathrm{m})$ and developing $(<800 \mu \mathrm{m})$ follicles.

Two of the six adult females taken between May and July appeared to be oestral. The vaginal epithelium comprised 8-11 cell layers, the superficial rows of cornified cells were swollen, considerably bloodshot, and their muscular walls thickened. In addition, the various uterine glands were well developed and the mucous membrane of the uterine lumen was star-shaped. The enlarged ovaries contained large $(<1650 \mu \mathrm{m})$ follicles that were ready to rupture, and were surrounded by a network of swollen blood vessels. Three other females showed the commencement of pro-oestrus. Here the vaginal epithelium consisted of 6-8 cell layers, and slight cornification was observed only in the upper layer of the functional epithelium. The ovaries contained many developing follicles and well developed egg cells $(<800 \mu \mathrm{m})$. The open-type lumen of the uterus and uterine horns was clearly visible, and both the uterine body and horns were enlarged and slightly bloodshot. One 3-year old female taken at the end of July was found to be pregnant, bearing three well developed embryos.

The functional state of the female reproductive organs was rather variable in August and September, and both post-ovulatory and pre-ovulatory females were recorded. The ovaries of two females taken in August contained three and four corpora lutea $(110-1200 \mu \mathrm{m})$. In addition, there were occasional, rather large follicular cavities, and large numbers of small and medium-sized regressing follicles.

The uteri of these females had large lumens, and their mucous membranes displayed tree-like infoldings, denoting response to progesterone. A further adult female, taken in August, possessed a large uterus with very bloodshot walls. Very 
large Graafian follicles were observed in the ovaries, indicating the onset of oestrus in that month. However, only the initial phase of the oestral cycle was observed in two females (older that 2 years) taken in September. Their vaginal epithelia consisted of 6-7 layers of cells, and showed no cornification. The ovaries were empty except for small numbers of rather small $(500-700 \mu \mathrm{m})$ follicles. Greater female functional maturity was observed at the end of autumn and in early winter. The uterine walls of two females captured in October were noticeably thickened and bloodshot, with the folds in the mucous membranes acquiring a spiral form. The ovaries contained large, mature follicles $(<1100 \mu \mathrm{m}$ in diameter $)$ with egg cells ready for ovulation. One female taken in October was pregnant, with an embryo in each uterine horn. The ovaries of a further adult female (also taken in October) had recently-ovulated follicles with corpora lutea present, as well as regressing follicles $(<450 \mu \mathrm{m})$.

Table 2. Number of otter cubs per litter in Belarus (data from Sidorovich 1991; $n=42$ litters with blind cubs up to 1 month) and NW Russia (data from Danilov and Tumanov 1976; $n=39$ litters).

\begin{tabular}{lccccccc}
\hline & \multicolumn{5}{c}{ Number of cubs/litter } & \multirow{2}{*}{ Mean } & SD \\
\cline { 2 - 6 } Area & 1 & 2 & 3 & 4 & & \\
\hline \multirow{2}{*}{ Belarus } & $n$ & 3 & 15 & 19 & 5 & 2.6 & 0.79 \\
& $\%$ & $(7)$ & $(36)$ & $(45)$ & $(12)$ & & \\
\multirow{2}{*}{ NW Russia } & $n$ & 2 & 17 & 15 & 5 & 2.6 & 0.78 \\
& $\%$ & $(5)$ & $(44)$ & $(38)$ & $(13)$ & & \\
\multirow{2}{*}{ Total } & $n$ & 5 & 32 & 34 & 10 & 2.6 & 0.78 \\
& $\%$ & $(6)$ & $(40)$ & $(42)$ & $(12)$. & & \\
\hline
\end{tabular}

A similar pattern was characteristic of adult females in November and December $(n=16)$, most of which were preparing for oestrus. Their uteri were large and bloodshot, the epithelia well developed, and the ovaries containing follicles ready for ovulation $(1600 \mu \mathrm{m})$, as well as numerous follicles in various stages of regression. Two females taken in November were pregnant, and three corpora lutea were clearly visible in the ovaries of each individual. In addition, numerous, small or medium-sized, growing or regressing, follicles were visible. One female (aged 5+) had a very large uterus ( $23 \mathrm{~g}$ ) with three bulges containing bent embryos measuring ca $10 \mathrm{~mm}$. Two females (aged 3+ and 4+) taken in early November and in mid-December were also pregnant, with two and three poorly developed embryos, respectively.

By examining the 10 pregnant females, a fecundity range of between 2 and 4 could be determined: 5 females with 2 embryos, 4 females with 3 embryos and one female with 4 embryos, on average 2.6 non-resorbing foetuses/pregnant female ( $\mathrm{SD}=0.7, n=10$ ) were recorded. The number of blind cubs found in holts was similar and ranged from 1 to 4 , on average 2.6 (Table 2). 


\section{Discussion}

From studying the reproductive organs of otters, some patterns of sexual maturity and reproduction can be determined. As in other large mustelids (e.g. badgers, wolverines), wild otters start to mate when older than two years of age, when both sexes become sexually mature. However, some individuals may commence breeding whilst still less than two years old.

There are also some reproductive differences within otter populations. The absence of a definite breeding period results in a reproductive mismatch for some individuals. It is well known that the activation of reproduction in carnivores is based on responses of the endocrine system, particularly to changes in day-length. However, different otters can commence breeding at different times of the year. This may result from the onset of the breeding being regulated not only by these factors, but also by others, perhaps the physiological condition of the individual, or physiological maturity, state of nourishment, age and season of birth, etc. Despite this, a considerable proportion of the males present at any one time are ready for sexual activity.

The results of studies by other authors (Fairley 1967, Stubbe 1969, 1977, Vshivtsev 1972, Heptner and Naumov 1974, Danilov and Tumanov 1976, Wayre 1979, Jenkins 1980, Kruuk et al. 1987, Heggberget 1988) further reinforce the suggestion that there is no strict reproductive conformity in otter populations. On inland rivers that are seasonally covered with ice, the more severe the winter (e.g. in northern and central Europe), the greater the degree of reproductive synchroneity observed, i.e. reproduction increasingly coincides with spring and beginning of summer. In the milder climates of western and southern Europe, cubbing becomes less seasonally distinct. In the northern coastal populations of otters, that do not experience winter freezing of waters, births occurred at different times of the year (e.g. in Norway, Heggberget 1988). The origin of this pattern is obscure, although it may lie within variations in the length of the period of otters gestation, or more probably, in higher-level co-ordination of the reproductive cycle. The origin of the latent phase is also obscure; in captivity the period of gestation is approximately two months and proceeds without delayed implantation (Wayre 1972, Reuther 1984, 1991, Robin 1989). In the zoological gardens at Novosibirsk (Russia) the gestation period of otters ranges from 51 to 72 days and there is no delayed implantation (Shilo and Nemshilova 1989), however, this may no invariably be the case in wild populations where feeding regimes are different, particularly in areas with severe winters. The structure of many wild otter populations is characterised by small numbers of young (usually 10-28\%), with a maximum of $38 \%$ having been reported from southern Sweden (Erlinge 1968). In spite of this, adult females comprise a maximum of about $40 \%$ of adult population, and fecundity is often between 2.5-3 cubs/female (Teplov 1953, Vshivtsev 1972, Heptner and Naumov 1974, Danilov and Tumanov 1976, Vaseneva 1976, Sidorovich 1991, 1992). These data seem to indicate that each year there are a certain number of 
non-breeding females (Chanin 1985, Sidorovich 1991). This may be the result of prolonged gestation periods following delayed implantation (Danilov and Tumanov 1976), or it may reflect reproductive declines in disturbed population structures (Sidorovich 1991), or the long period of young independence may block the next oestrus cycle of a female.

Under conditions where there is no definite breeding season, pair formation is vitally important. This is because studies have shown that disturbed population structures as a result of over-hunting lead to increases in the numbers of non-breeding females and declines in reproductive rates (Sidorovich 1991). Therefore, a continuous cycle of oestrus in otters (Wayre 1979, Trowbridge 1983, Mason and Macdonald 1986) is of great importance, being an adaptive peculiarity of the species which allows the normal course of the reproductive process. According to Wayre (1979), the female comes into oestrus every 40 to 45 days, and remains so for approximately 14 days. Trowbridge (1983) states that the mean length of the cycle of oestrus is 36 days, but it may range from between 17 to 51 days.

In general, however, otter fecundities in Belarus and north-western Russia are very similar to those reported from western Europe (e.g. Jenkins and Harper 1982).

Acknowledgements: Many thanks are due to Dr H. Griffits (University of Leeds) for improving the English of this article, and providing much helpful advice. We thank very much Drs Z. Pucek and B. Jędrzejewska for their editorial comments. Drs V. Ivanovsky, I. Kochanovsky and A. Kozulin helped us in collecting otter reproductive organs.

\section{References}

Chanin P. 1985. The natural history of otters. Christopher Helm, London: 1-179.

Cler R. V. 1941. [Oestral and pregnancy cycles of Mustelidae (mink, sable, marten)]. Zootechnical Institute, Moscow: 1-196. [In Russian]

Danilov P. I. and Tumanov I. L. 1976. [Mustelids of north-west of the USSR]. Nauka, Leningrad: 1-225. [In Russian]

Erlinge S. 1967. Food habitats of the fish otter Lutra lutra L., in south Swedish habitats. Viltrevy 4: 317-443.

Erlinge S. 1968. Territoriality of the otter Lutra lutra L. Oikos 19: 186-209.

Fairley J. 1967. Food of otters (Lutra lutra) from Co. Galway, Ireland, and notes on other aspects of their biology. J. Zool., Lond. 166: 469-474.

Heggberget T. M. 1984. Age determination in the European otter Lutra lutra lutra. Z. Säugetierk. 49 : 299-305.

Heggberget T. M. 1988. Reproduction in the female European otter in central and northern Norway. J. Mammal. 69: 164-167.

Heptner V. G. and Naumov N. P. 1974. Die Säugetiere der Sowjetunion, 2. VEB Gustav Fisher Verlag, Jena: $1-278$.

Jenkins D. 1980. Ecology of otters in northern Scotland. I. Otter (Lutra lutra) breeding and dispersion in mid-Deeside, Aberdeenshire in 1974-79. J. Anim. Ecol. 49: 737-754.

Jenkins D. and Harper R. T. 1982. Fertility in European otters (Lutra lutra). J. Zool., Lond. 197: 299-300. 
Klevezal G. A. and Kleinenberg S. E. 1967. Age determination of mammals from annual layers in teeth and bones. Israel Program for Scientific Translations, Jerusalem: 1-128.

Kruuk H., Conroy J. W. H. and Moorhouse A. 1987. Seasonal reproduction, mortality and food of otter (Lutra lutra L.) in Shetland. Symp. zool. Soc. Lond. 58: 263-278.

Mason C. F. and Macdonald S. M. 1986. Otters. Ecology and conservation. Cambridge University Press. Cambridge: 1-236.

Reuther C. 1984. Otter in captivity. First results of an enquiry. Otters. Journal of the Otter Trust, 1(8): 45-56.

Reuther C. 1991. Otters in captivity - a review with special reference to Lutra lutra. Proc. V. intern. Otter Coll. Hankensbuttel, 1989: 269-307.

Robin K. 1989. Haltung und Zucht des Fischotters Lutra lutra in zoologischen Garten: Ein Oberblick. Populations okologie marderartiger Säugetiere, Halle: 181-192.

Sidorovich V. E. 1991. Structure, reproductive status and dynamics of the otter population in Byelorussia. Acta theriol. 36: 153-161.

Sidorovich V. E. 1992. [Otter population structure in Byelorussia]. Bull. MOIP, Otdel Biol. 96(6): 43-52. [In Russian]

Shell G. 1955. Biology of the laboratory mouse. McGraw Hill, Inc., New York: 1-216.

Shilo R. A. and Nemshilova J. V. 1989. [Otter activity in captivity]. [In: Zoos and their importance in the protection of wild animals. V. E. Flint, ed]. Kainar, Alma-Ata: 136-143.

Stephenson A. B. 1977. Age determination and morphological variation of Ontario otters. Can. J. Zool 55: $1577-1583$

Stubbe M. 1969. Zur Biologie und Zum Schutz des Fischotters Lutra lutra L. Arch. Naturschutz und Landschaftsforsch. 9: 315-324.

Stubbe M. 1977. Der Fischotter Lutra lutra (L., 1758) in der DDR. Zool. Anz. 3-4: 265-285.

Teplov V. P. 1953. [Otter in Pechoro-Ilich Reserve]. Bull. MOIP, Otdel Biol. 58(6): 7-16. [In Russian]

Trowbridge B. J. 1983. Olfactory communication in the European otter (Lutra l. lutra). Ph. D. thesis, University of Aberdeen.

Vaseneva A. Y. 1976. [Reproduction, age and sex composition of otter population in Far East. Collected articles of scientific and technical information]. Kirov 54-55: 9-18. [In Russian]

Vshivtsev V. N. 1972. [Otter of Sakhalin]. Nauka, Novosibirsk: 1-106. [In Russian]

Wayre P. 1972. Otter breed at Norfolk Wildlife Park. International Zoo Yearbook 7: 128-130.

Wayre P. 1979. The Private Life of the Otter. Batsford, London: 1-112.

Received 14 July 1993, accepted 7 February 1994. 